\title{
Sustainable Building and Integrated Construction Waste Management Challenges and Strategies for China
}

\author{
Zixiang Chen, Ping Liu, Yunhui Yang \\ Kunming Metallurgy College, Kunming, China
}

Keywords: Sustainable Building, Integrated Waste Management; Life Cycle Management; BIM

\begin{abstract}
China's rapid march toward urbanization makes sustainable building a priority at all levels of governments. Construction industry contributes not only a great portion of economic output, but also contributes a large of portion of solid waste stream which causes the serious negative impacts towards environment and ecosystem in China. Therefore, sustainable development is of paramount importance to China's future. Hence, this paper outlines sustainable building challenges in China currently, and enlightens the importance of Sustainable Building and Integrated Construction Waste Management process through the principle of Life Cycle Design, and the interactions and synergies among BIM, sustainability building technology, which will maximally alleviate construction waste situation by way of reduce, reuse and recycle the construction waste in China.
\end{abstract}

\section{Introduction}

Currently, the world is faced with several environmental problems which continue to harm lands, jeopardizing production of natural resources, the greenhouse gas effects which caused by carbon dioxide emissions is predicted to be increased to 40 billion tons in year 2030, if no tremendous effort is thrown in to mitigate it. Thus, consideration of sustainable building becomes a top agenda at the global level. Sustainable building bears considerations not only related to building performance, but also attempts to address the triple bottom line, specifically, the environmental, economic and social impacts of the building industry. Sustainable building is environmentally responsible and resource-efficient throughout a building's life-cycle, which has largely emerged from construction communities of practitioners working to define beneficial processes and practices and create mechanisms to recognize and encourage their use in the world, and has been evolving worldwide for almost 30 years. As global climatic and ecological problems have become serious, regulations such as UNFCCC (United Nations Framework Convention on Climate Change) and laws relevant to wastes in most countries have gradually reinforced.

Building industries in China is resulted of great impact on the environment, and inevitably accompanied by construction, remodeling and demolition of buildings, roads, bridges, flyover, subways, runways, factories and other similar establishments which generate gigantic construction waste materials. Building industry is one of the major industries that generate wealth to the country in China, and decades of urbanization has led to unchecked environmental degradation, resource depletion, and growing populations without access to quality public services.

\section{Sustainable Building and Integrated Construction Waste Management Situation}

Sustainable building is transforming the construction responsibility and impacts on the environment from siting, design, construction, operation and maintenance. Sustainable Building and Integrated Construction Waste Management is a successful concept that has evolved after decades of solid waste management experience. In developed countries like U.S.A, U.K., Canada, Singapore, Germany, Australia, Norway and Brazil etc. 94\% of architects, engineers, consultants and owners report engaging in some level of green building or sustainable building, either project certified to a global green building rating system or built to qualify for such a system.

1) Sustainable Building Situation in China

Sustainable building movement is growing rapidly in China. China is becoming one of the most 
active Green building (Sustainable building) markets since China has the largest construction market in the world. In recent years, China has introduced a series of stringent codes to encourage sustainable building solutions which do not add substantial building costs but can result in significant sustainability over the lifecycle of the building so as to mitigate serious environmental and pollution problems, thus China's strong intention is to become a leader in the global sustainable building industry. There could be a real green building revolution when sustainable construction developments start spreading from tier- 1 cities to tier- 2 and 3 cities in China. However, comparison with developed countries like USA and Europe, sustainable building practice is still in initial stage in China in terms of the quantity and sustainability technology. China needs to make improvements on its green building standards, rating system, government policies, incentive measures, and practices to adapt to its vast geographical situation.

2) Integrated Construction Waste Management Situation in China

Integrated sustainable solid waste management strategies are usually based on the hierarchy of waste management i.e. Reduce-Reuse-Recycle-Compost-Dispose. The hierarchy of construction and demolition waste management simply advocates that the best approach to construction and demolition waste management is to reduce waste generation and separate potential recyclables at source to improve the quality of materials for reuse. With respect to resource-saving and environment-friendliness, a strategic hierarchy of the integrated construction waste management methods in a descending order is reduction, reusing, recycling, compost, incineration, and landfill. Construction and demolition waste is a worldwide issue due to the rapid growth of towns and cities, it occupies the largest share of overall waste generation in many countries with their economic growth. As one of the major fixed asset formation sectors and cornerstone industries in the national economic system of China, the construction industry has been undergoing rapid development for almost two decades. China has surpassed the United States as the world's largest municipal solid waste generator since 2004 . China's annual solid waste quantities will increase by another $150 \%$ to over 480,000,000 tons in 2030, more than twice the amount that will be generated in the US at the same time.

3) Chinese Construction Waste Management Comparison with Industrialized Countries

In the European Union, construction waste accounts for $30 \%$ of the total waste (European Commission 2010). In the USA, construction waste constitutes $29 \%$ of the total solid waste and $35 \%$ of landfill space is taken up by construction waste. Many European countries have made considerable achievements to utilize the construction wastes in the past decades. The countries like U.K, U.S.A., France, Denmark, Germany and Japan have succeeded in developing economically feasible technologies for recycling up to 80 or 90 percent of construction and demolition waste. The waste recovery rate in Germany is one of the highest in the world.

Construction and demolition waste constitute up to $50 \%$ of all solid waste in China, which are generated from the demolition of built structures for renovation or complete removal or renewal due to fast urbanization. All this construction and demolition waste has to be removed from the place of origin - in most cases it is considered unusable and is discarded. Chinese government review and improve its waste management system by way of reducing the landfill proportion and increase the proportion of waste reduce, reuse, and recycling, reaching a high recycling rate for construction and demolition waste. In 2013, about 1 billion tons of construction waste in China, including dismantling buildings produce about 740 million tons of construction waste, new building account for about 260 million tons of construction waste. Unfortunately, the common practice of Chinese waste hierarchy model still adopts conventional landfill or open storage on refuse sites for waste disposal at present, and has not attached enough importance to construction and demolition waste generation and disposal, the landfill occupied more than $80 \%$ for waste disposal, China's utilization of construction debris only account for $5 \%$ of total Construction and demolition Waste.

\section{BIM Technology Drives on Sustainable Building \& Integrated Construction Waste Management}

As major trends in the global architecture design industry, the interactions and synergies among 
BIM sustainable building and integrated construction waste management have linked with its model-based technology database of project information for building design, engineering, and construction management, which can be accessed and shared among different project participants, and also can be integrated with other programmes for construction estimating, scheduling, and project management. BIM has arisen as a solution to support the supply, integration and management of information throughout the building life cycle, there is a significant increase of BIM tools being utilized to achieve project goals specifically related to sustainable building and integrated construction waste management, such as LEED certifications or similar etc. BIM has been the perfect tools to improve the building performance and overall project outcome due to the holistic design approach adopted. With BIM, the project team is much easier to assess selected and specified building materials for high postconsumer recycled content, rapidly renewable materials, extracted and manufactured locally sourced materials. And which includes an assessment of potentially hazardous material components during construction and occupancy, and final demolition. For post-build activities, a comprehensive pre-design waste management plan builds in a waste recycling process that encourages recycling behavior, making it easy for future occupants to move segregated, recyclable material horizontally and vertically in a building. Therefore, by exploring the power of BIM in visualization, coordination, simulation and optimization to promote sustainable building and integrated construction waste management, the project team can perceive the dynamics of building systems better and thus have the opportunity to experiment different options and optimize the overall sustainable building oriented design and substantially reduce the need for re-gathering or re-formatting information for building life cycle information management.

\section{Sustainable Building and Integrated Construction Waste Management Challenges in China}

Chinese government has recognized the urgency of widely implementing sustainable building and integrated construction waste management, which will simultaneously boost the economic efficiency. There is a growing consciousness among the severe environmental strains on infrastructure and the impact pollution on their quality of life in China. The new leadership has acknowledged this, and translated it into government policy, pledging to invest significantly into the sustainable building movement. However, China's targets on sustainable building plans are facing a variety of challenges:

1) Sustainable Building Technology Challenges

China is the largest construction market to apply sustainable buildings technology and knowhow in the coming years. Yet the Chinese sustainable building revolution is still in its infancy. Sustainable buildings pose new challenges to building design and architecture professionals. China lacks sustainable building technology and knowhow on expertise of integrated sustainable building design and construction among engineers, designers and constructors. Integrated building design, a relatively new concept, not only optimizes overall energy performance, minimize materials use, recycle and cut down on waste. China also lacks project team members including professional construction contractors, well-educated and experienced sustainable building specialists who can properly implement sustainable projects, these are the big challenges.

2) Sustainable Building High Cost Challenge

The higher up-front cost of sustainable buildings is a significant challenge. Developers, building owners and policymakers view the up-front costs as the biggest barrier to sustainable building in China. Though additional project costs are always generated by modifications, the right design and project plan can help avoid a lot of extra costs. Developers in China are focusing on quick profits rather than long-term sustainability; they still commonly believe sustainable building means simply tacking on green components, which alone can cost a part of money more than traditional building materials. Building contractors are concerned over the perception of additional time employees will spend segregating waste, and concern more on the construction and demolition waste management revenues and disposal cost savings offset labor costs. Currently, most consumers in China pay more attention to price rather than the long term benefits of sustainable building. Only when sustainable 
building benefits justify the incremental costs will the market embrace sustainable buildings for the long run.

3) Challenge of Low Awareness Level on Sustainable Building

The building industry remains a conservative culture resistant to change in China. Old convenient habits of disposing of construction and demolition waste by landfilling are often hard to break. Since sustainable building concepts are still comparatively new in China, from government department's staffs to developers, investors and many of the design, construction, supervision, property management personnel, are simply not aware of all the reuse and recycling opportunities, all the industry professionals are lack of sustainable building basic knowledge and awareness that sustainable buildings can reduce materials costs and improve living comfort. In general, green investment can always be paid back by lifetime sustainable benefit. As the people's awareness and cognition of sustainable building concept is low, investors are not willing to pay higher initial costs, even though it would result in lower resource expenditures over the long-term. However, awareness of resource-efficient construction practices is lacking in China. This growing waste stream has significant impact for the society, environment and economic development in China.

4) Sustainable Building and Legal Standards Challenge

China is a large country crossing at least three climate zones. One major challenge is China's huge range of geography and climates, which make it difficult to roll out a national standard sustainable building regulation. Chinese green building standards are rather narrow in scope and lack a strong regulation framework to incorporate integrated construction waste management, the standards fall short of international standards and most are less stringent than industrialized countries. Chinese government has also put strict policies to minimize the amount of construction and demolition waste entering Landfills. Modifying standard construction and demolition contract specifications to require or encourage construction and demolition waste management has been met with resistance. Somehow, policies and guideline have not been translated in the form of strong legal instruments and enforcement being applied by building industry in China. Hence, the most contractors adopted their company initiatives for waste minimization during construction process which clearly does not reflect to current policies implemented by government. The integrated construction waste management remains poorly implemented in construction projects in China. In addition, specific laws have yet to be developed to further reduce landfill of non-recycled waste.

5) Challenge of Life Cycle Design

Life Cycle Design is one of the biggest challenges in China for sustainable construction and integrated construction waste management. The principles of Life Cycle Design provide important guidelines on building design, engineering, and construction management, and for the selection of building materials. A material's life cycle can be organized into three phases: Pre-Building; Building; and Post-Building, a "cradle-to-grave" analysis of sustainable building, from the gathering of raw materials to their ultimate disposal, provides a better understanding of the long-term costs of materials and environmental impact, these stages parallel the life cycle phases of the sustainable building itself. The sustainable building practice expands and complements the classical building design concerns of economy, utility, durability, and comfort. Due to long time fragmentation operation in project life circle management in China, the design institutes only carry out the design works and are normally not responsible for building and supervision of the construction works. This requires close cooperation of the design team, the architects, the engineers, and the owner at all project stages but it is rarely practiced in China.

6) Challenge of Limited Recycle Market

There are limited recycling markets in China resulting in most construction and demolition waste discarded as landfill, rather than by way of resource-saving and environment-friendliness, a strategic hierarchy of the integrated construction waste management methods. Markets often either doesn't exist locally or recyclers do not accept the broad spectrum of construction and demolition waste. For example: asphalt and gypsum wallboard can only be recycled in a few parts of the country at this time. Some specialized recyclers only accept one type of waste and this often makes waste management costly and inconvenient, such as metals. Also, many recyclers do not provide 
pickup and transport service adding to the cost and inconvenience. The lack of efficient integrated construction waste management leads to increasing demand of landfill volume, hazardous wastes from construction and demolition sites can cause health problems (asbestos, liquids). Furthermore, empirical evidences confirmed that solid waste recycle process is $5 \%$ and $95 \%$ of waste collected being disposed at landfills in China.

7) Sustainable Building Education Challenge

One of the biggest challenges in China is the Life Cycle Design, construction and operation education on sustainable building and integrated construction waste management. Universities across the China are quickly embracing sustainable building international practices, and green technology education is becoming an essential course to professional training. But China still lack straightforward and practical education for advancing sustainable building and integrated construction waste management practices and outcomes at colleges and universities. Drawing on international experience in sustainability provides additional impetus for making progress in this arena of sustainable building profession education in China..

\section{Sustainable Building and Integrated Construction Waste Management Strategies for China}

Chinese government should take the strategies which will be adequately publicized and promoted to the entire construction industry which tend to be aware of environmental requirements and practices. The proposed framework will be highlighting new strategies and guidelines that can be used in practices for minimizing construction waste in order to applying good practices in construction industry among Chinese contractors and stockholders. The strategies could include:

1) Incentives Policies and Mechanism on Sustainable Building and Waste Management

The purpose of the incentives policies and mechanism is to ensure the building professionals will properly dispose the construction waste through tracking its destination as well as complying with the government policies. China should opt for maximum prevention and reduction of waste and more environmentally friendly methods of waste disposal for using recycled materials in projects, it should also provide an economic incentives for building professionals who are reducing the construction and demolition waste, and subsidizing recycling companies to increase the amount of recycling being performed or providing incentives for reducing waste and reusing recycled materials in projects.

2) Punishments Policies and Mechanism on Construction Waste Management

It is highly recommended that Chinese government should enforce stronger waste management policies, such as levying heavier construction waste disposal fees at landfills, and levying fines or penalties for extremely poor waste management. Chinese government is taking some actions to tackle the waste problems by establishing a policy which requires all stakeholders of the project to prepare waste management plans for disposal and strictly to minimize the amount of construction and demolition waste entering landfills. The building parties involved should try their best to reduce, reuse and recycle the construction before it disposes to landfills to avoid fines or penalties.

3) Sustainable Building and Integrated Construction Waste Management Education

Chinese government should enforce stronger cooperation programmes with the U.S. and European countries to stay abreast of global sustainable building technology and knowhow on expertise of sustainable building and integrated construction waste management and education developments. Through increased sustainable building education in schools and training on the job, the culture of the construction industry can be changed to view environmental protection as a higher priority than it is now, which will lead to the adoption of integrated construction waste management practices.

4) BIM Technology Adoption on Sustainable Building Life Cycle Design

It is also highly recommended that Chinese government should take solid incentives policies for BIM adoption through partnership with vendors, professional associations, open standard organizations and academic/research institutions, so as to keep pace with or advance the U.S. and Western European countries. BIM is being developed in the U.S. and Western European countries 
to efficiently achieve complex building performance analyses to ensure an optimized sustainable building Life Cycle Design, enabling the project teams typically possess a spectrum of expertise in a myriad of disciplines to greatly improve sustainable building performs and integrated construction waste management as per the criteria on environmental impacts.

\section{Discussion Remarks}

Briefly, on a more global scale, it is very urgent to promote sustainable construction and integrated construction waste management so as to satisfy the increasing demand of raw materials for building activities and to reduce the emissions responsible for global warming and pollution, and reduce negative issues related to environment, social, and economic situation. Similarly to other developed countries, the hierarchy of integrated waste management is emphasizing on reduce, recycle and reuse the waste, sustainable building and integrated construction waste management are extremely vital for China in coping with future sustainable development. Sustainable building and integrated construction waste management are the best approach to control the waste load situation in China, the "Polluter Pays Principle" has been introduced by the Chinese government which enacted under environmental law. However, there is still a long way for China.

\section{References}

[1] China resources comprehensive utilization of the annual report of 2014 (in Chinese), The national development and reform commission.

[2] Begum, R. A., Satari, S. K. and Pereira, J. J., (2010). Waste Generation and Recycling: Comparison of Conventional and Industrialized Building Systems. American Journal of Environmental Sciences, 6(4), 383-388.

[3] Yashuai LI, Xueqing ZHANG, Comparison and Analysis of International Construction Waste Management Policies, Construction Research Congress 2012.

[4] Autodesk. Autodesk 360 for BIM Collaboration, Data \& Lifecycle Management for AEC (2011).

[5] World Green Buiding Trend, Smart Market Report (2014), McGraw-Hill Construction.

[6] M. F. a. Goosen, "Environmental management and sustainable development," Procedia Engineering, vol. 33, pp. 6-13, Jan. 2012.

[7] D. Kralj, "Innovative systemic approach for promoting sustainable innovation for zero construction waste," Kybernetes, vol. 40, no. 1/2, pp. 275-289, 2011.

[8] European Commission (2010) Being wise with waste: the EU's approach to waste management. 